\title{
掃流砂の停止機構に関する研究
}

\section{REST MECHANISM OF THE TRANSPORTED PARTICLES AS BED-LOAD}

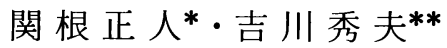 \\ By Masato SEKINE and Hideo KIKKAWA
}

\begin{abstract}
Each of the particles transported as bed-load will rest on the bed after a certain passage, mostly due to being held up with the unevenness of bed surface particles and rarely to die-out of reflection energy during the impingement of the particle on the bed. In order to investigate the mechanism of this process, the uneven arrangement of bed particles are simulated stochastically, based on the observation by a video analysis, and a simulation model of bed-load movement is constructed. The validity of this model is verified by experimental data, and as a result, the characteristics of this process, that is Step-length and Moving-period, are clarified and the equation for estimation of these values can be developed as a function of dimensionless tractive force $u^{*} / w_{0}$. It is confirmed that the estimated values by these expressions agree well with the experimental values obtained by several researchers.

Keywords : bed-load, step-length, rest mechanism of moving particle
\end{abstract}

1. 目 的

著者らは, 掃流砂の運動を, 離脱・流送・停止の 3 つ の素過程に分け, そのおのおのの運動特性を確率論的に 説明しようとする研究を進めてきた。本研究では，これ まで明らかにしてきた離脱・流送過程についての成 果 ${ }^{1) ~ 3)}$ を踏まえ, 停止過程についても確率論的に扱うこ とにする. そして, その結果として, この過程を特徴付 けるパラメーターである Step-length, Moving-period の平均的な特性や確率分布について明らかにする.

解析にあたっては, 現象をより広範囲にわたつて検討 するため, 掃流砂の運動に関する数值シミュレーション を行う. 本シミュレーション・モデルは, 移動中の粒子 についての運動方程式と, 移動粒子と河床粒子との衝突 モデルとからなるものであり, 流送砂の流送過程の解 析”の際にも同様の計算を行っている.ただし, その場 合には, 河床を構成する粒子が規則的に平坦かつ密に並 んでいるとしたため, 一度移動を開始した粒子はほとん よ゙停止することなく流送されてしまい, 結果的に停止過

* 正会員 工博 早稲田大学助手 理工学部土木工学科 ( T160 新宿区大久保 3-4-1)

** 正会員 工博 早稻田大学教授 理工学部土木工学科 (同上)
程に関する知見を得ることはできなかった．そこで，本 論では, 新たに, 河床面上に露出している河床表層の粒 子の高さを確率論的な手法を使ってモデル化し，これに より生成されるランダム河床上での数值模擬を行う.

\section{2. 現象のモデル化}

\section{（1） モデルの概要}

本研究で行う数值模擬は, 河床粒子の配列の仕方に関 する新たなモデルを加えたことを除けば, 前報”で説明 したものとほぼ同様である. すなわち，これは，掃流砂 の successive saltation 運動を, その運動方程式を差分 化して解くことにより解析しようというもので, その解 法の際に必要な個々の saltation の初期条件については, 移動粒子と河床粒子との衝突事象の結果として与えられ る.

運動方程式としては, 前報と同様に, 式（1）を用い ることにし,これを差分化した後, Runge-Kutta 法を使っ て解くことにした.

$$
\begin{aligned}
& m_{1} \cdot\left(d^{2} x / d t^{2}\right)=-D_{x} \\
& m_{1} \cdot\left(d^{2} y / d t^{2}\right)=-D_{y} \\
& m_{1} \cdot\left(d^{2} z / d t^{2}\right)=-D_{z}-m_{2} \cdot g \\
& \text { ここに, } m_{1}=\left(\pi \cdot d^{3} / 6\right) \cdot \rho\left(\sigma_{s}+C_{M}\right), \quad m_{2}=\left(\pi \cdot d^{3} / 6\right) \text {. } \\
& \rho\left(\sigma_{s}-1\right),\left(d: \text { 粒径, } \rho: \text { 水の密度, } \sigma_{s}\right. \text { : 粒子の比重, }
\end{aligned}
$$


$C_{M}$ : 仮想質量係数).また,式中の $D_{x}, D_{y}, D_{z}$ は, 式 $(2)$ で定義される抗力ベクトルの各方向成分であり，これは， 相対速度ベクトル $\vec{V}_{r}$ の大きさに応じて決まる抗力係数 $C_{D}(t)$ との関係で, 次式のように表わされる.

$$
\left.\begin{array}{l}
\vec{D}=\left(D_{x}, D_{y}, D_{z}\right)=\rho / 2 \cdot C_{D}(t)\left(\pi d^{2} / 4\right)\left|\vec{V}_{r}\right| \cdot \vec{V}_{r} . \\
\vec{V}_{r}=\left(d x / d t-U_{\lambda}(z(t)), d y / d t, d z / d t\right) \\
C_{D}(t)=24 / R_{e \rho}(t)+3 / \sqrt{R_{e p}(t)}+0.34 \\
R_{e \rho}(t)=\left|\vec{V}_{r}\right| \cdot d / \nu
\end{array}\right\} \ldots .
$$

また, 式（3）中の流体の時間平均流速 $U_{f}(z(t))$ につい ては，対数分布則を適用することにより与えることにし ている.なお，本論でも，士砂の運動に及ぼす流体の乱 れの影響が顕著でない領域を研究の対象としているた め，式中に乱れの影響を表わす項を入れることはしてい ない（ただし，乱れの効果を取り込むことにより，掃流 砂から浮流砂への遷移についてや，両者が混在する場合 の全流砂の特性についての解析も可能となるが，これに ついては別途研究を進めており, 続報として報告する予 定である).

\section{（2）河床粒子の配列に関するモデル}

河床粒子の配列に関するモデル化に先立って行った実 験結果のビデオ解析によれば，河床面上に露出している 粒子の高さは，粒径スケールではあるが，流下方向およ び横断方向にランダムに変化していることがわかった。 そこで，その分布の仕方を調べたところ，図一1のよう な結果が得られた。これは, 河床面上に露出している粒 子の中心の高さの存在確率密度分布の一例である.この 図より, 露出している河床粒子の中心の位置 $z_{b c}$ が, 平 均河床のまわりに分散 $\sigma_{z}=d / 3(d:$ 粒径 $)$ の正規分布 をすることが明らかになった．このことは，平坦河床と いえども, 確率として, 平均河床のまわりに最大一粒径 程度の凹凸まで河床表面に生起している可能性があると いうことを表わしており，妥当な結論といえる．また， 流下方向あるいは横断方向への配列の仕方について， ス ペクトル解析を行ったところ, 特に強い相関性は認めら れなかった. なお, 著者らの実験の範囲内では, 無次元 掃流力の大きさによらず，上記の結果がほぼ満足される ことを確かめている.しかし,掃流力がさらに大きくなっ た場合には，河床波が形成されることになり，上記のこ とが成り立たなくなるが, その場合には本論で述べるモ

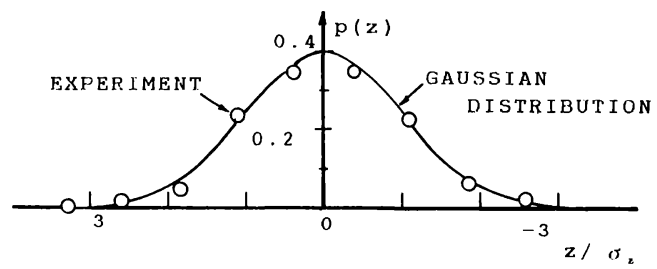

図一1 河床表層の粒子中心の高さの存在確率密度分布
デルの修正が必要となると考える。

以上の知見に基づき, 本モデルでは, 任意点での河床 粒子の位置 $z_{b c}$ を，正規乱数を用いてランダムに与える ことにした。 また, 計算では, 実際の現象に少しでも近 づけるため，粒子の運動を三次元的に追跡するために， 条件として与えるべき河床粒子の配列の仕方についても 三次元的な広がりをもち，流下方向および横断方向にラ ンダムに変化するものとした. ただし, 隣接する粒子間 の相対的な位置関係については，そのなす角が安息角を 越えることがないように配慮している。

図一2には，このようにして得られたモデル河床の一 例を示している.この図より，生成された粒子オーダ一 の凹凸のうち，まれに，隣接粒子より半粒径あるいはそ れ以上深い「窪み」(図中の矢印参照) が生じているこ とがわかる.このことは, 実験時のビデオ解析の結果と も一致する. また，その際の観察結果から，移動粒子が 停止に至るのは, その粒子が, 衝突時あるいは衝突後に この「窪み」の部分に入り込み，この凹の部分を構成す る隣接した二粒子と交互に衝突を繰り返すことにより， その全エネルギーを損失した場合である，と考えられる ことから, 本計算では, 移動粒子が, この「寉み」の部 分にトラップされ，上下流いずれの方向にも流送されな い状態に至ったとき，その粒子は停止したと判断するこ とにしている.ただし，このような停止パターンとは別 に, 衝突時の運動量交換の結果として, 河床粒子が運動 を開始し，移動粒子自体は停止してしまうこともまれに は生じることがわかっているが，本計算ではこのことを モデルに取り入れることはしていない，図一3には，参 考までに，計算によって得られた粒子の軌跡の一例を示 しており, 図の矢印の位置で停止している（図中の楕円
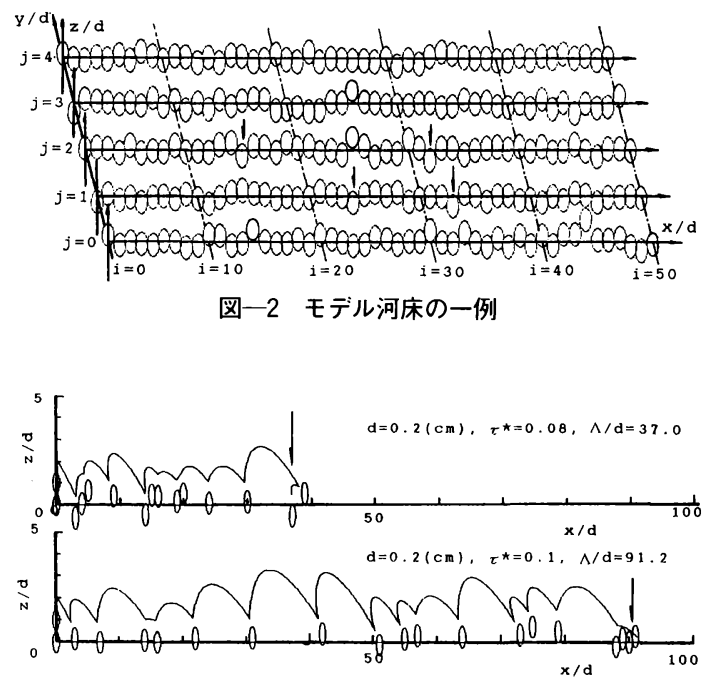

図一3計算による移動粒子の軌跡の一例 
は，移動粒子と接触した河床粒子のみを，また，曲線は 移動粒子の中心の軌跡をそれぞれ示したものである。な お, 同図は, $x$ および $z$ 方向の縮尺の比を約 $1: 3.5$ に とって描いたものである).

計算にあたっては, 境界条件として, 移動粒子が到達 する可能性のある領域における河床粒子の位置を, 上記 の方法により，あらかじめ与えておくことにし，すべて の $z_{b c}$ の值を既知量として，1つの粒子の離脱開始から 停止までの一連の運動を追跡する.計算では,粒子の個々 の軌跡を約 200 回追跡することにし，それにより得られ る約 200 ケース分のデータを母集団として統計処理し, 移動粒子の停止事象についての確率変数の平均值および その分布についての特性を調べている，ただし，河床粒 子の配列のパターンを, 各ケースごとに無作為に変えて 計算している．なお，計算回数については，100回前後 で各特性量の平均値が一定の值に達することがわかり， 平均量に関する限り，この程度の回数で十分であると考 えられる。

\section{（3）移動粒子の河床粒子との接触判定}

移動している粒子が，このように不規則に配列された 河床粒子に接触したか否かについては，各瞬間ごとに次 の条件を満足しているか否かによって判断することがで きる.すなわち， $\vec{L}$ を河床粒子の中心位置からみた移 動粒子の中心位置の位置べクトル, $d$ を粒径とすれば,

$$
\begin{aligned}
& |\vec{L}| \leqq d \\
& L=\left\{\begin{array}{l}
l_{x} \\
l_{y} \\
l_{z}
\end{array}\right\}=\left\{\begin{array}{l}
x(t) \\
y(t) \\
z(t)
\end{array}\right\}-\left\{\begin{array}{l}
X_{b c}(i, j) \\
Y_{b c}(i, j) \\
Z_{b c}(i, j)
\end{array}\right\}
\end{aligned}
$$

ここに, $\{x(t), y(t), z(t)\}$ および $\left\{X_{b c}(i, j), Y_{b c}(i, j)\right.$, $\left.Z_{b c}(i, j)\right\}$ は, 任意の時刻 $t$ における移動粒子の中心の 座標，および河床粒子の座標をそれぞれ表わしている.

また, $i$ および $j$ は, $x$ および $y$ 方向へ付けた河床粒子 番号であり, 関数 INT $(x)$ を $x$ を越えない最大の整数 を表わすものと定義すれば，次式で表わされる.

$$
\left.\begin{array}{l}
i=\operatorname{INT}(x(t) / d+0.5) \\
j=\operatorname{INT}(y(t) / d+0.5)
\end{array}\right\}
$$

また，移動粒子の真下にある粒子の番号を $i_{0}$ および $j_{0}$ で表わすことにすると, 各瞬間に, $(i, j)=\left(i_{0}, j_{0}\right)$, $\left(i_{0}+1, j_{0}\right),\left(i_{0}, j_{0}-1\right),\left(i_{0}, j_{0}+1\right)$ に対応する 4 つの粒子 に対して，式（4）による判定を行う必要がある.すな わち, 移動粒子は, その真下に存在する河床粒子と, こ れに隣接する粒子に対して, 各瞬間ごとに, 両者の位置 関係をチェックしながら跳躍を繰り返すことになる。し たがって，これら 4 つの河床粒子のいずれについても， 式（4）が満足されなかった場合に限り，粒子は河床と 接触することなく， saltation 運動を継続する。

\section{（4）衝突位置の決定}

式（4）を満足する（すなわち, 衝突された）河床粒 子 $(i, j)$ に対して, その表面上のどの位置に衝突するか については, 次のように考える. いま, 衝突点を $\left(x_{0}\right.$, $\left.y_{0}, z_{0}\right)$ とすると,

$$
\begin{aligned}
& \left\{\begin{array}{l}
x_{0} \\
y_{0} \\
z_{0}
\end{array}\right\}=\left\{\begin{array}{c}
d \cdot \cos \phi \cdot \cos \psi \\
d \cdot \cos \phi \cdot \sin \psi \\
d \cdot \sin \phi
\end{array}\right\}+\left\{\begin{array}{c}
X_{b c}(i, j) \\
Y_{b c}(i, j) \\
Z_{b c}(i, j)
\end{array}\right\} \cdots(6) \\
& \phi=\arctan \left(l_{z} /|\vec{L}|\right) \\
& \psi=\arcsin \left(l_{y} / l_{x}\right)
\end{aligned}
$$

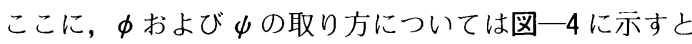
おりである。

\section{（5）衝突直後の初速度べクトルの決定}

移動粒子と河床粒子との衝突の直後における移動粒子 の初速度は, 次のような座標変換を行うことにより, 簡 単かつ合理的に決定することができる.

まず， $X_{P}-Y_{P}-Z_{P}$ 座標系 (これは元の $x-y-z$ 座標系 と同一) でみた衝突点 $\mathrm{P}_{1}$ およびその直前 $(d t$ 時間前) の点 $\mathrm{P}_{0}$ の座標 $\left(X_{P 1}, Y_{P_{1}}, Z_{P_{1}}\right)$ および $\left(X_{P 0}, Y_{P 0}, Z_{P 0}\right)$ は, 最終落下速度ベクトル $\vec{V}_{e p}=\left(U_{e}, V_{e}, W_{e}\right)$ を用いて, 次 式のように表わされる.

$$
\begin{aligned}
& \left\{\begin{array}{l}
X_{P 0} \\
Y_{P 0} \\
Z_{P 0}
\end{array}\right\}=\left\{\begin{array}{l}
x_{0} \\
y_{0} \\
z_{0}
\end{array}\right\}-d t \times\left\{\begin{array}{c}
U_{e} \\
V_{e} \\
W_{e}
\end{array}\right\} \\
& \left\{\begin{array}{l}
X_{P 1} \\
Y_{P 1} \\
Z_{P 1}
\end{array}\right\}=\left\{\begin{array}{l}
x_{0} \\
y_{0} \\
z_{0}
\end{array}\right\}
\end{aligned}
$$

次に，衝突された河床粒子の中心を原点に取った $X_{Q}-$ $Y_{Q}-Z_{Q}$ 座標系でみた上記の二点 $\mathrm{P}_{0}, \mathrm{P}_{1}$ の座標を $Q_{0}\left(X_{Q 0}, Y_{Q 0}, Z_{Q 0}\right), Q_{1}\left(X_{Q 1}, Y_{Q 1}, Z_{Q 1}\right)$ とし, この座標系で の衝突点 $Q_{1}$ を球の天頂 $S_{1}(0,0, d)$ に移す坐標変換を施 すと, 変換後の $X_{S}-Y_{S}-Z_{S}$ 座標系でみた衝突直前・直後 の点の座標 $S_{0}\left(X_{s 0}, Y_{s 0}, Z_{s 0}\right), S_{2}\left(X_{s 2}, Y_{s 2}, Z_{s 2}\right)$ は, マ トリックス $[M]$ を用いて，

$$
\begin{aligned}
& \left\{\begin{array}{l}
X_{s 0} \\
Y_{s 0} \\
Z_{S 0}
\end{array}\right\}=[M]\left\{\begin{array}{c}
X_{Q 0} \\
Y_{Q 0} \\
Z_{Q 0}
\end{array}\right\} \\
& \left\{\begin{array}{c}
X_{S 2} \\
Y_{s 2} \\
Z_{s 2}
\end{array}\right\}=e\left\{\begin{array}{c}
X_{S 1}-X_{S 0} \\
Y_{S 1}-Y_{S 0} \\
Z_{S 1}-Z_{s 0}
\end{array}\right\}+\left\{\begin{array}{c}
X_{S 1} \\
Y_{S 1} \\
Z_{S 1}
\end{array}\right\}
\end{aligned}
$$

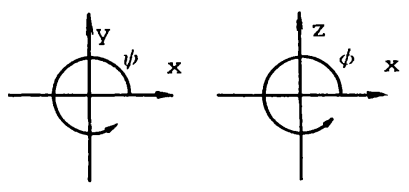

図一4 $\phi$ と $\psi$ の取り方 
で求められる.ここに， $e$ は反発係数である社1).この 式は, $X_{s}-Y_{s}-Z_{s}$ 座標系でみた衝突前後の速度ベクトル $\vec{V}_{e s}, \vec{V}_{0 s}$ の間に,

$\vec{V}_{0 s}=e \times \vec{V}_{e s}$.

が成り立つことから求めたものである.

さらに, 上記の逆変換を施すと, 元の $X_{P}-Y_{P}-Z_{P}$ 座標 系でみた衝突直後の点 $P_{2}$ の座標 $\left(X_{P 2}, Y_{P 2}, Z_{P 2}\right)$ が次式 のように求められる.

$$
\left\{\begin{array}{c}
X_{P 2} \\
Y_{P 2} \\
Z_{P 2}
\end{array}\right\}=[M]^{-1}\left\{\begin{array}{c}
X_{S 2} \\
Y_{S 2} \\
Z_{S 2}
\end{array}\right\}+\left\{\begin{array}{l}
X_{b c}(i, j) \\
Y_{b c}(i, j) \\
Z_{b c}(i, j)
\end{array}\right\}
$$

したがって, 次の saltationの初期条件と与えるべき 衝突直後の初速度ベクトル $\vec{V}_{0}=\left(U_{0}, V_{0}, W_{0}\right)$ は, 次式 により求めることができる.

$$
\left\{\begin{array}{c}
U_{0} \\
V_{0} \\
W_{0}
\end{array}\right\}=(1 / d t) \times\left\{\begin{array}{c}
X_{P 2}-X_{P 1} \\
Y_{P 2}-Y_{P 1} \\
Z_{P 2}-Z_{P 1}
\end{array}\right\}
$$

なお，式（8)，（9）中のマトリックス $[M],[M]^{-1}$ については，次のように定義される.

$[M]=\left[\begin{array}{ccc}\sin \phi \cdot \cos \psi & \sin \phi \cdot \sin \psi & -\cos \phi \\ -\sin \psi & \cos \psi & 0 \\ \cos \phi \cdot \cos \psi & \cos \phi \cdot \sin \psi & \sin \phi\end{array}\right]$

$[M]^{-1}=\left[\begin{array}{ccc}\sin \phi \cdot \cos \psi & -\sin \psi & \cos \phi \cdot \cos \psi \\ \sin \phi \cdot \sin \psi & \cos \psi & \cos \phi \cdot \sin \psi \\ -\cos \phi & 0 & \sin \phi\end{array}\right]$

\section{3. 停止過程の諸特性}

\section{（1）モデルの妥当性の検証}

本論では, 停止過程を特徴付けるパラメーターとして, Step-length および Moving-period について検討する が，それに先だって，まず，シミュレーションの妥当性 の検証を行う. 図一5,6では, 粒子の鉛直方向への存在 確率密度分布 $f(Z)$ および移動速度分布 $u_{s}(Z)$ について の比較を行っている. 図中のプロットは粒径 $5 \mathrm{~mm}$ のガ ラス・ビーズを用いた著者らの実測結果 ${ }^{11}$ であり，また， 実線は実験条件と同一の条件で計算することにより得ら れた結果を示している.ただし, 実測の際には, $z$ の原 点を河床粒子の存在し得る上限の高さに設定しているた め,これとの比較のため, 図中の計算結果も, 高さの補 正を行ったものを示している.この図一5,6より，計算

注 1) 土屋・青山4によれば, 反発係数 $e$ が, 移動床では掃 流力によらず 0.5 前後の值となり, 固定床では 0.8 程度 まで及ぶと報告されている。ここでは，これらを考慮し， しかも本モデルにより現象を最もよく説明する值とし て, $e=0.65$ という值を用いている. なお，前報では, $e=0.7$ としていることを付記する.
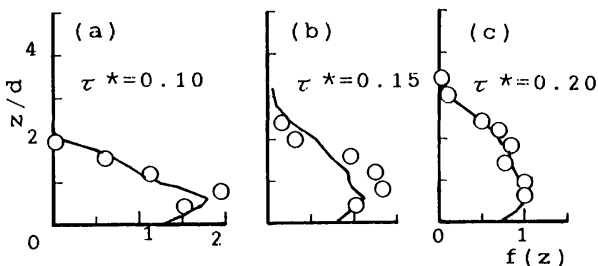

図一5 粒子の鉛直方向への存在確率密度分布 $\boldsymbol{f}(\boldsymbol{Z})$ の比䡈
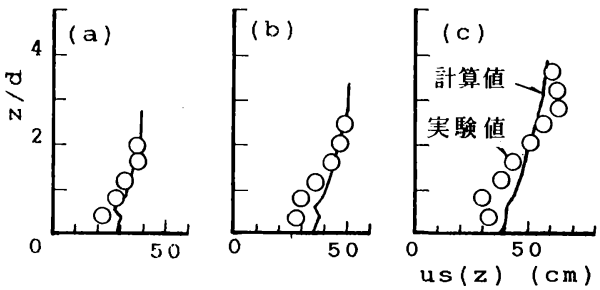

図-6 粒子の移動速度分布 $\boldsymbol{u}_{s}(\boldsymbol{Z})$ の比較

值は実測值を，よく説明していることがわかる.また， 図一7では, 無次元掃流力 $\left(\tau^{*}=u^{* 2} / s g d ; s: \sigma_{s}-1\right.$, $\sigma_{s}$ : 粒子の比重, $g$ : 重力加速度）の変化に伴う粒子の 平均跳躍高さ $h_{s}$ について調べており,これについても 両者は比較的よく一致していることがわかる（図中の曲 線が計算值)

以上により，本モデルは，掃流砂の運動を忠実に再現 していると判断され，以下，本モデルを用いて掃流砂現 象の諸特性を明らかにする.

\section{( 2 ) Step-length の評価}

“Step-length $\Lambda$ ”は，河床を離脱した粒子が再び河床 に停止するまでに流下する距離として定義される．これ については, これまで, 中川・辻本 ${ }^{5)}$, 矢野・土屋・道 上")，および，篠原・椿7)による実験的研究がなされて いるが，粒子をラグランジェ的に追跡することが容易で なく, かつ, 停止の判断が難しいことなどから, 得られ たデータにはばらつきが大きく，值の変化傾向がわかる のみで，その実態が十分把握できていないというのが実

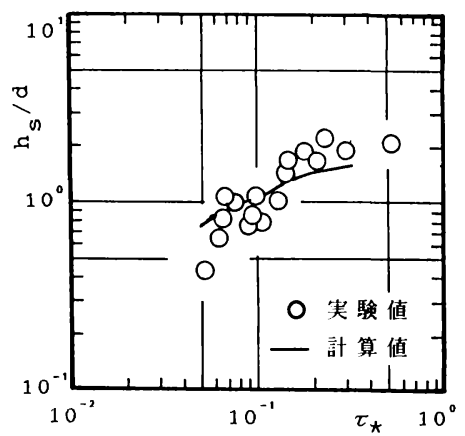

図一7 粒子の平均跳躍高さ $h_{s}$ の比較 
状である. 一方, 理論的あるいは半理論的な研究につい ては, 中川・辻本によりなされたものがあり,これは, 矢野らの実測結果とも一致するものであるが, steplength が $\tau^{*}=0.07$ 前後で最小値をとる分布となること が示されている. しかし，著者らの実験時の観察によれ ば, 限界掃流力 $\left(\tau^{*}=0.045\right)$ 付近では, 河床を離脱し た粒子は, 周期的に粒径の数倍から数十倍程度の距離を 移動するにすぎず， $\tau^{*}=0.07$ 付近での粒子の移動と比 較して際立って緩やかな運動であることから， $\tau^{*}=$ 0.045 の方が $\Lambda$ が大きくなるとは考えられない.そこで, 本論では, このような点を考慮して, 現象を合理的にモ デル化した数值計算を行い, その結果から, 帰納的に step-length 等のパラメーターの特性を知り, その推定 方法を導き出そうとするものである.

本論では, 河床構成材料として, 直径 $d$ が $0.1 \sim 1.0$ (cm) の範囲の均一粒径の砂を対象とし, 無次元掃流 力 $\tau^{*}$ を $0.05 \sim 0.25$ 程度の範囲で変化させて計算して いる（上記の無次元掃流力の範囲は, これまで報告され

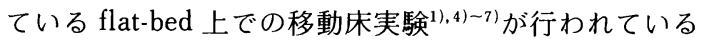
範囲とほぼ一致する). 計算では, 河床に静止していた 1 つの粒子が河床から離脱した直後を, 時間の原点とし て取ることにし，その後の粒子の運動軌跡を追跡するも のである. 図一8には計算により得られた平均 Steplength $\Lambda$ (1つの条件に対して 100 200 回の試行計算 により求まった Step-length の平均值）の, 掃流力に伴 う変化の仕方を示している.ここに, 図の縦軸には無次 元 Step-length $\lambda(=\Lambda / d)$ を, 横軸には摩擦速度と粒 子の静水中での最終沈降速度との比 $u^{*} / w_{0}$ をそれぞれ 取っている.この図より， $\lambda$ を $u^{*} / w_{0}$ との関係で整理 すると粒径が異なる場合にも相似性が保たれ，その関係 が, 式（15）で表わされる図中の実線によって説明され

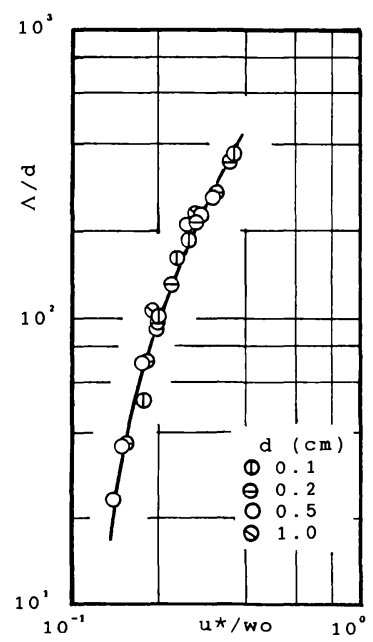

図一8 Step-length の計算結果

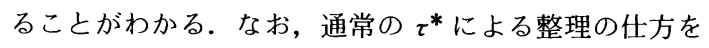
したのが図一10 (図中のプロットの記号は, 図一8, 9 と 同一であり, 計算值を大きなプロットで, 実測值を小さ なプロットで表わしている) であり，この図より，特に 計算結果に着目すれば, プロットが粒径によって明確に ばらついていることがわかる. そこで, ここでは, $u^{*} /$ $w_{0}$ による整理の仕方の方が適切であると判断した社2). また，このような整理の仕方は, 浮流砂が共存するよう な流れまで拡張して考えていく際に, 特に有効となると 考える.

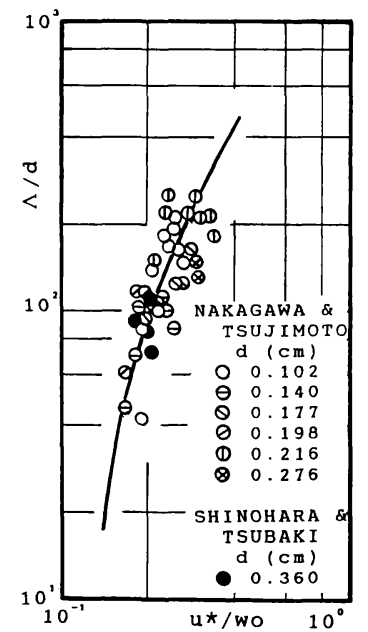

図一9 $\Lambda$ の実測值と計算值との比較 (1)

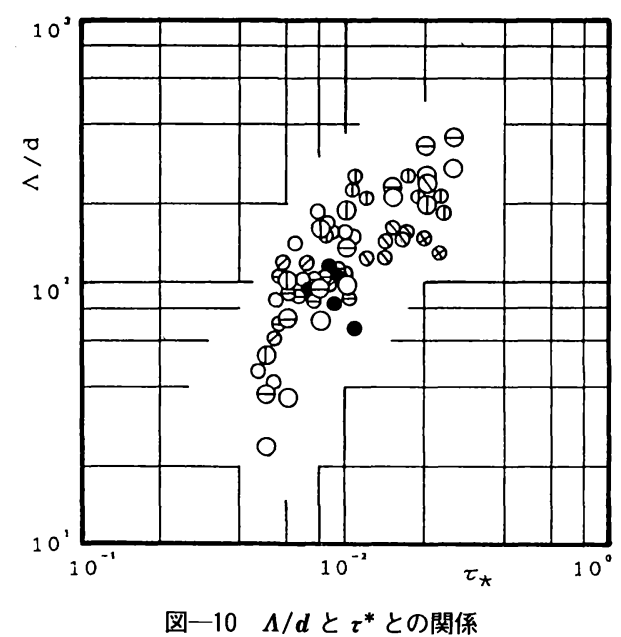

注 2） $\tau^{*}$ と $u^{*} / w_{0}$ とは，ともに無次元掃流力を表わすパラ メーターであり, 両者の間には次式の関係がある. $\tau^{*}=\left(4 / 3 \cdot C_{0}\right) \times\left(u^{*} / w_{0}\right)^{2}$

したがって，粒子レイノルズ数 $R_{e d}$ によって抗力係数 $C_{D}$ が変化する $R_{e d}<10^{3}$ の範囲では, $\tau^{*} と u^{*} / w_{0}$ とは 比例関係にはない. 


$$
\lambda=\Lambda / d=\alpha_{1} \cdot\left(u^{*} / w_{0}\right)^{3 / 2} \cdot\left\{1-k_{c} /\left(u^{*} / w_{0}\right)\right\}
$$

ここに， $\alpha_{1}$ および $k_{c}$ は定数であり， $\alpha_{1}=2500, k_{c}=$ 0.12 で与えられる. なお， $k_{c}$ については，各粒径の粒 子に対する限界掃流力に相当する值を表わすと考えられ る. そこで, $u_{c}^{*} / w_{0}\left(u_{c}^{*}\right.$ は限界掃流力に対する摩擦速 度を表わす）の值をシールズ関数を用いて算出してみる と，粒径によって異なるものの， $d=0.05 \sim 1.0(\mathrm{~cm})$ の範囲の砂に対して，0.13〜0.18 程度の值となること がわかった．これは，限界掃流力の定義の仕方にもよる が, $u^{*} / w_{0}=u_{c}^{*} / w_{0}$ のとき必ずしも $\lambda=0$ となる（すな わち，粒子が動かない）わけではなく，ある有限の值を とることもあり得ることから，上記の值はほぼ妥当なも のといえる.

次に，式 (15) あるいは計算結果の妥当性を検討する

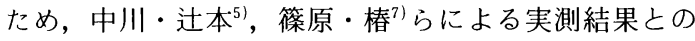
比較を行った。 その結果が, 図一9〜11である.ここで, 図一9中の実線は式（15）による值を表わしている。ま た，図一11中の実線は, 実測值と式（15）による計算 值との比 $r$ (=実測值/計算值 $)$ が 1 の場合に, 破線は $r=0.5$ あるいは 2.0 の場合に相当している.これらの 図より, 多少のばらつきはあるものの, 式（15）による 計算值は実測值を比較的よく説明しており，この式に よって Step-length を精度よく推定することが可能であ ることが明らかになった。なお，上記のばらつきの程度 を定量的に調べるため, 図一12では，実測値と計算値 との差をとって求めた誤差分布（図の横軸は（実測値一 計算値) /計算値 $=r-1 ）$ を示している. この図より, 両者の相対的な誤差が正規分布（図中の実線に相当）に 従うことが明らかになった。このことは，実測值を真値 とすれば,これと式（15）による推定值との比が, 分散 $\sigma=0.5$ 程度のガウス分布で表わされる誤差範囲に入る ような，比較的精度よい值を式（15）が与えることを表 わしている，一方，見方を変えれば，この図は，実測値 が, 式 (15) で与えられる一連の傾向から図のような分

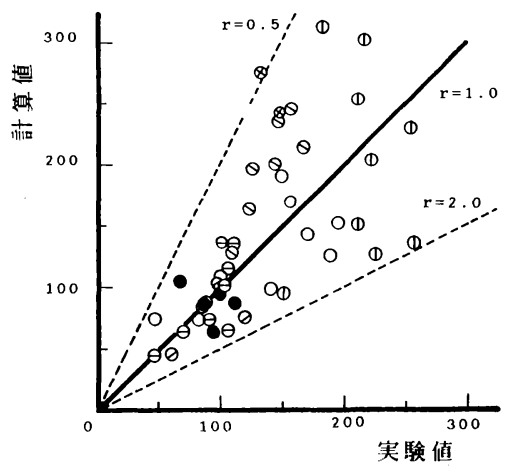

図一11 $\Lambda$ の実測値と計算值との比較（2）

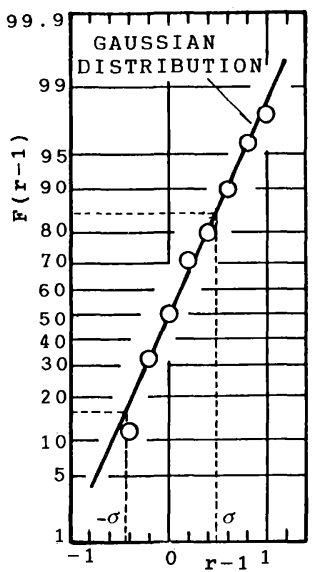

図一12 $\Lambda$ の実測值と計算值との差の確率分布

布に従ってばらついていることを表わしているとも考え られる。

以上は Step-length の平均値についての性質である が，実際にはこれも確率量であるため，平均值のまわり にある分布を取ることが予想される。 そこで，その生起 確率密度分布 $f_{x}(x / \Lambda)$ について検討したところ, 図一 13 のような結果が得られ，これまで指摘されてきたと おり指数分布に従うことがわかった. したがって，この ことからも本モデルの妥当性が確かめられた。なお，計 算結果が図中の折れ線のようにばらつくのは，データの サンプル数が必ずしも十分多くないことによる.

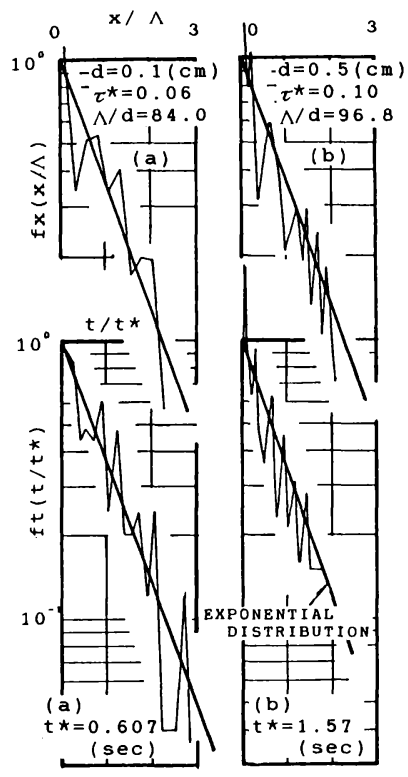

図一13. $\Lambda$ と $t^{*}$ の生起確率密度分布 


\section{(3) Moving-period の評価}

“Moving-period $t$ *”，粒子が離脱してから停止す るまでに要する運動の寿命時間として定義される。一方, オイラー的な見方をすれば，これは，断面内の土砂濃度 が定常化するのに要する時間に相当するとも考えられ， Step-length とは, 次の関係にある.

$\Lambda=U_{s} \times t^{*}$

ここに, $U_{s}$ は粒子の断面内平均移動速度である.

計算により得られた $t^{*}$ を， $u^{*} / w_{0}$ との関係で整理し たものが図一14である，この図より，プロットが図中 の実線（すなわち，式（17））によってうまく表わされ ることがわかる.

$$
T^{*}=t^{*} \times \sqrt{s g / d}=\alpha_{2} \cdot\left\{1-k_{c} /\left(u^{*} / w_{0}\right)\right\}
$$

ここに， $\alpha_{2}$ は定数であり，プロットの傾向を最もよく 説明する值として， $\alpha_{2}=250$ としている.なお, 前報2) では，この $t^{*}$ に関する情報が十分ではなかったため， これを $0.5 \sim 2.0$ 秒（平均的には 1 秒程度）として解析 を進めたが, 本研究により, 一連の研究で対象とした粒 径・掃流力の範囲内では，これがほぼ妥当な值であるこ とが明らかになった。

次に，この計算結果の妥当性について検討する必要が

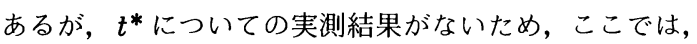
実測結果のある断面内平均移動速度 $U_{s}$ についての比較 を通じて間接的にこれを行うことにした。すなわち， $t^{*}$ に対して得られた式（17）上前節で得られた式（15） とを，式（16）に代入すると，USについての関係を表 わす式 (18) が導かれる.

$U_{s} / \sqrt{s g d}=\left(\alpha_{2} / \alpha_{1}\right) \times\left(u^{*} / w_{0}\right)^{3 / 2}$

そこで, この式の適合性を調べるため, 著者ら゙および
Francis $^{8)}$ の実測值との比較を行ったのが，図一15であ る（図中には，本計算結果も併記している). 図一15 よ り, 計算值は実測結果と良好な一致を示し, しかも,こ れらが式（18）の関係（図中の実線）を満足することが わかる，ただし，同図では，特に砂粒子に限って比較を 行っており，比重が異なる粒子については検討の対象と はしていない（Francis の実測の場合には，砂粒子以外 に，比重をさまざまに調整した粒子を用いて実験を行っ ている).

以上により， $t^{*}$ に関する計算結果および式 (17) の 妥当性が検証され, Moving-period については, 式 (17) によって推定できるとの結論が得られた.

また, $t^{*}$ の生起確率密度分布 $f_{\mathrm{T}}\left(t / t^{*}\right)$ についても, その一例を図一13に示すとおり, 指数分布に従うこと がわかっている.

\section{4. 流砂量式の誘導}

掃流砂の各過程を特徵付けるパラメーターについて は，前報および前章までの研究により明らかにすること ができた。 そこで，ここでは，これらに基づいた新たな 流砂量式を誘導する.

単位幅当たりの流砂量 $q_{B}$ は, 通常,

$$
q_{B}=N_{B} \times P_{S} \times U_{S} \times t^{*}=N_{B} \times P_{S} \times \Lambda .
$$

で定義される. 式中の $N_{B}$ は河床単位面積上に存在する 粒子体積であり, $\left(k_{3} / k_{2}\right) \cdot d$ で与えられる(ここに, $k_{2}, k_{3}$ : 面積および体積に関する形状係数). また, $P_{S}$ は pick-up-rate であり, 前報〉で次式を得ている.

$$
P_{S}^{*}=P_{s} \cdot \sqrt{d / s g}=\alpha_{3} \cdot \sqrt{u^{*} / w_{0}} \cdot\left\{1-k_{c} /\left(u^{*} / w_{0}\right)\right\}^{3}
$$

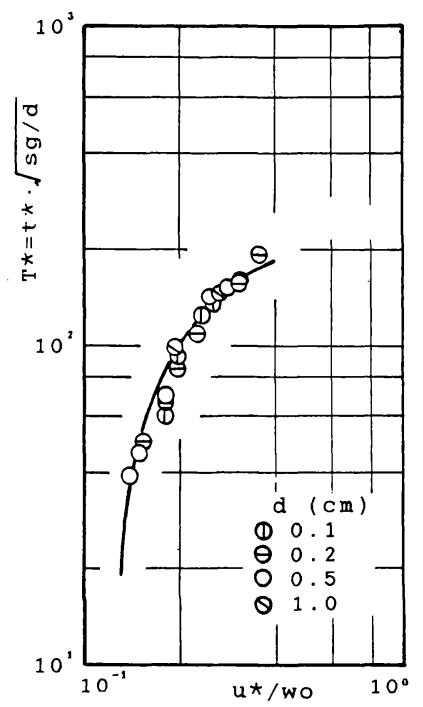

図一14 Moving-period の計算結果

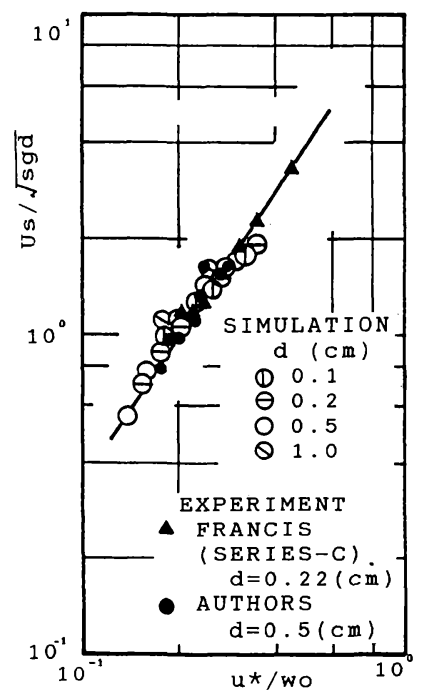

図一15 断面平均移動速度の実測結果との比較 
ここに, $\alpha_{3}$ は定数であり， $\alpha_{3}=0.08$ で与えられる.

したがって，式（15）（あるいは（17）と（18）およ び（20）を式（19）に代入することにより，次式のよう な流砂量式が導かれる。

$$
q_{B}^{*}=q_{B} / \sqrt{s g d^{3}}=\alpha_{4} \cdot\left(u^{*} / w_{0}\right) \cdot\left\{1-k_{c} /\left(u^{*} / w_{0}\right)\right\}^{4}
$$

ここに, $\alpha_{4}$ は, $\alpha_{4}=\alpha_{1} \times \alpha_{3} \times\left(k_{3} / k_{2}\right)=133$ で与えられる 定数である.

次に，このようにして導かれた式（21）の適合性につ いて調べることにする，図一16は，実測値と式 (21) との比較を行ったものである. 図中のプロットは, 著者 らおよび Gilbert ${ }^{91}$, 篠原・椿 ${ }^{7)}$, 矢野・土屋・道上 ${ }^{6)}$ に よる実測結果を表わしている，ただし，同図では，本モ デルが適用可能と考えられる平坦床 (flat-bed) 上で得 られたデータを, 比較の対象として用いている.この図 より, 式 (21) は実測値より若干大きめの值を与えるも のの, 比較的精度よい流砂量の推定式であることがわ かった.なお, 本モデルでは, 主に, saltation 形式で 流送される土砂の運動を対象としている（ここでは, 滑 動・転動形式での土砂の輸送を, 跳躍長の限りなく短い

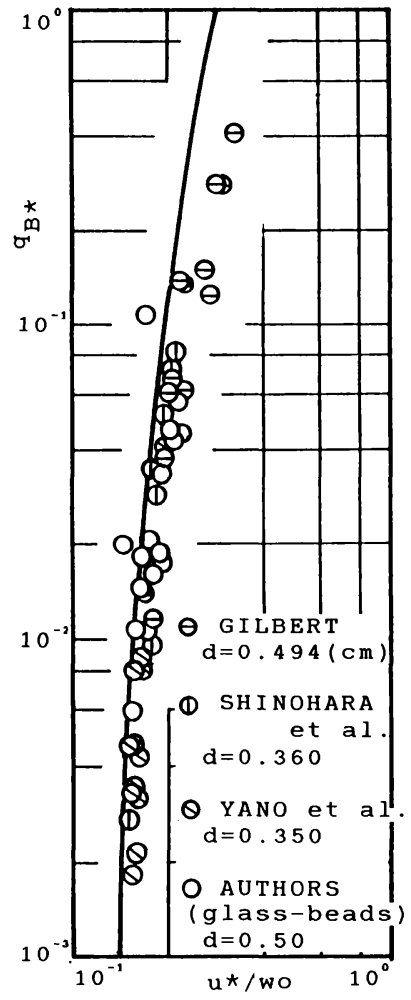

図一16 掃流砂量 saltation 形式での輸送とみなしている) ため，式 (21) により推定される值は, 流砂量の上限值を与えるものと 考えられる.

\section{5. 結 論}

本論では, 土砂の停止の原因として, 河床表層の粒子 が不規則でしかも必ずしも密な配列をしているとは限ら ないことを考慮して，この河床粒子群の高さの変化につ いての簡単なモデル化を行い, これを掃流砂輸送モデル の一部に取り込んだ新たな数值模擬を試みた. その結果 として, 掃流砂の停止過程を特徴付けるパラメーターで ある Step-length および Moving-period の確率論的な性 質が明らかとなり，併せてその平均值を定量的に評価す る式を導くことができた，さらに，著者らがこれまでに 明らかにしてきた他の過程のパラメーターとの積の形で 流砂量を精度よく推定することができるようになった。

本研究では, 河床が均一粒径の砂により構成され，し かも河床が flat である場合に限って解析を進めてきた が, 今後は, 河床構成材料が混合粒径になった場合や, 河床に Ripple 等の河床波が形成された場合についても 検討していく必要があると考えている.

本研究の遂行にあたり, 文部省科学研究費奨励研究 (A)「流砂モデルの再検討とその統一化に関する研究」 （研究代表者：関根正人）の援助を得た. 記して謝意を 表します。

\section{参 考 文 献}

1）関根・吉川：掃流砂の流送機構に関する研究, 土木学会 論文集, No. 351, 1984.

2）関根・吉川：エネルギー関係から見た掃流砂現象の特性, 土木学会論文集, No. 351, 1984.

3）関根・吉川：流砂に関する従来理論の再検討, 早稲田大 学理工学研究所報告, No. 114, 1986.

4）土屋・青山：水流による砂れき Saltation の機構（2), 京都大学防災研究所年報, 第 13 号 B, 1970.

5）中川・辻本：水流による砂れきの移動機構に関する基礎 的研究, 土木学会論文報告集, No. 244, 1975.

6）矢野·土屋・道上：砂れきの流送機構の確率過程として の特性について, 京都大学防災研究所年報, 第 11 号 B, 1968.

7）篠原・椿：河床砂れきの移動機構に関する一考察, 九州 大学応用力学研究所報, 第 10 号, 1957.

8) Francis, J. R. D. : Experiments on the Motion of Solitary Grains along the Bed of a Water-Stream, Proc. Royal Society of London, A332, 1973.

9) Gilbert, G. K. : The Transportation of Debris by Running Water, U.S. G.S. Professional Paper 86, 1914.

(1988.6.14 - 受付) 